\title{
Synergistic effect of El Niño and the North Pacific Oscillation on wintertime precipitation over Southeastern China and the East China Sea Kuroshio area
}

\author{
Yue Sun ${ }^{1} \cdot$ Jianping $\mathrm{Li}^{1,2}$ (1) \\ Received: 17 June 2021 / Accepted: 23 September 2021 / Published online: 25 January 2022 \\ (c) The Author(s) 2022
}

\begin{abstract}
Wintertime precipitation in China is most pronounced over the southeastern area, and the Kuroshio in the East China Sea anchors a prominent precipitation band over the warm side of the sea surface temperature front. Previous studies have suggested that many factors contribute to the interannual variation of the precipitation over southeastern China (SC), whereas less attention has been paid to precipitation variability over the East China Sea Kuroshio (ECSK) area. This study focuses on the interannual variation of wintertime precipitation over the SC and ECSK areas. Empirical orthogonal function analysis reveals a spatially uniform pattern from SC to the ECSK area. Composite analysis shows that an El Niño event intensifies wintertime precipitation over our target region, and this effect is tripled when an El Niño follows a positive North Pacific Oscillation (NPO) event in the previous winter. The positive NPO event in the previous winter intensifies the El Niño event via the Victoria mode ocean bridge and the subsequent Bjerknes feedback. In comparison with single-factor El Niño events, a much weaker Walker cell induced by the joint event induces a much weaker regional Hadley cell through anomalous descending motion over the western tropical Pacific. The weakened regional Hadley circulation over the western Pacific directly enhances the precipitation over the SC and ECSK area. In this study, the synergistic effect of an El Niño event and a positive NPO event indicates that the influence of the El Niño event can be amplified by the positive NPO event in the previous winter.
\end{abstract}

Keywords Wintertime precipitation $\cdot$ Synergistic effect $\cdot$ El Niño $\cdot$ North Pacific Oscillation

\section{Introduction}

Wintertime precipitation in China is most prominent over the southeastern area (Gao et al. 2020), where it accounts for $\sim 15 \%$ of total annual precipitation ( $\mathrm{Li}$ and Ma 2012), and this proportion has an increasing trend (Sui et al. 2013). Southeastern China (SC) is very vulnerable to changes in precipitation on account of its rapid population growth and economic development (Qin et al. 2015). Precipitation variability over this region has dramatic societal, economic, and

Jianping Li

ljp@ouc.edu.cn

1 Frontiers Science Center for Deep Ocean Multispheresand Earth System (FDOMES)/Key Laboratory of Physical Oceanography/Institute for Advanced Ocean Studies, Ocean University of China, Qingdao 266100, China

2 Laboratory for Ocean Dynamics and Climate, Pilot Qingdao National Laboratory for Marine Science and Technology, Qingdao 266237, China agricultural effects (Easterling et al. 2000; Alexander et al. 2006; Huang et al. 2010; Zhang et al. 2015). It is of great importance to deepen scientific understanding of wintertime precipitation variability over SC and to improve its prediction skill.

El Niño is the most significant air-sea interaction phenomenon over the tropical Pacific Ocean on interannual timescales and has far-reaching influences on precipitation variability (Dai and Wigley 2000; Sun et al. 2015), including boreal wintertime precipitation variability over SC (Zhou et al. 2010; Zhou and Wu 2010; Yuan et al. 2014; Gao et al. 2020). Positive precipitation anomalies occur over SC during the mature phase of El Niño (Wang et al. 2000; Zhang and Sumi 2002; Wu et al. 2003). During an El Niño winter, the weakened Walker circulation triggers anomalous descending motion and an anticyclone over the western North Pacific, which leads to anomalous lower-level southwesterlies and enhances the transport of water vapor from the sea surface to SC. This abundant supply of moisture and the ascending motion induced by a local meridional circulation over East 
Asia result in more winter precipitation over SC (Wu et al. 2010, 2017; Zhou et al. 2010; Duan et al. 2013; Lu et al. 2017; Zhang et al. 2017; Gao et al. 2020).

The most recent study to date has demonstrated that the boreal spring North Pacific Victoria mode (VM) is significantly correlated with the following winter precipitation over the SC, and can be regarded as an effective predictor of wintertime precipitation over the SC about 1 year in advance (Zou et al. 2020). A positive VM is closely linked to the development of El Niño through surface air-sea coupling and evolution of subsurface ocean temperature anomalies (Ding et al. 2015, 2017, 2018, 2019; Pu et al. 2019). The most significant correlation between the VM index and Niño 3.4 index occurs when the VM leads El Niño by 11 months. A strong positive $\mathrm{VM}$ in spring notably enhances the wintertime precipitation in SC by triggering an El Niño event in the following winter (Zou et al. 2020).

A positive VM can be forced by a positive North Pacific Oscillation (NPO, Rogers 1981), and acts as an oceanic bridge connecting the wintertime positive NPO event and the subsequent winter El Niño event (Ding et al. 2015). A wintertime positive NPO event is an important extratropical forcing for the development of the subsequent wintertime El Niño event via the seasonal footprinting mechanism (Vimont et al. 2001, 2003a, b; Alexander et al. 2010). Anomalous sea level pressure over the southern NPO lobe can be used to forecast the Niño 3.4 index $12-15$ months in advance (Anderson 2007). These results suggest that a positive NPO event may have an effect on wintertime precipitation over the $\mathrm{SC}$ by inducing a positive $\mathrm{VM}$ that then results in an $\mathrm{El}$ Niño event.

The East China Sea Kuroshio (ECSK) area is adjacent to the east coast of SC. Existing studies have focused mainly on precipitation variability over the land, and less attention has been paid to the interannual variation of wintertime precipitation over the ECSK area, which is of significant economic value in supporting heavy shipping, fishing, and oil-drilling activities (Xie et al. 2002). The Kuroshio is a strong western boundary current in the North Pacific, and forms a sharp sea surface temperature (SST) front in the East China Sea. Previous studies have demonstrated that the climate effect of sharp SST fronts can extend to the free atmosphere by inducing deep convection and anchoring a precipitation band over the warm water (Minobe et al. 2008, 2010; Xu et al. 2011; Sasaki et al. 2012). By analyzing high-resolution precipitation observations, Sun et al. (2020) revealed that the variation of wintertime frontal precipitation over the Gulf Stream is related to the North Atlantic Oscillation on interannual timescales. This suggests that the SST frontal-scale precipitation may be modulated by basin-scale atmospheric circulation. In addition, the model simulations of Xu et al. (2019) indicate that SC precipitation is suppressed by heavy frontal precipitation in the ECSK area through anomalous regional overturning circulation. The relationship between the SC precipitation and ECSK precipitation in the observations remains to be investigated.

Aside from the influences of single factors, the joint effect of two factors is attracting more attention, for the reason that an atmospheric variation usually arises from two or more processes working or interacting together ( $\mathrm{Li}$ et al. 2019). Synergistic effects between the tropics and the mid to high latitudes are important pathways to influence the East Asian climate (Li et al. 2019). For instance, the synergistic effect of El Niño-Southern Oscillation (ENSO) and the spring North Atlantic Oscillation on the East Asian summer monsoon (EASM) may provide an effective tool for EASM seasonal prediction (Wu et al. 2009). ENSO and Tibetan Plateau snow cover also have a synergistic effect on the EASM (Wu et al. 2012). Moreover, midlatitude atmospheric upstream disturbances and oceanic subtropical SST front intensity variability have synergistic effects on the wintertime western Pacific jet stream (Chen et al. 2020). Thus, it may be more useful to give higher priority to investigating the joint effect of two or more factors than to single factor analysis.

In this study, we reveal the characteristics of interannual variation of wintertime precipitation over SC and the ECSK area by using high-resolution observations of precipitation. The results show that precipitation variation over SC and the ECSK is synchronous and spatially uniform. Previous studies found that the interannual variability of wintertime precipitation in SC may be attributed to many factors, such as El Niño, East Asian winter monsoon intensity, SST anomalies over the South China Sea, Siberian High intensity, and the position of the East Asian Trough (Zhang et al. 2015). Instead of examining single factors, we investigate the joint effect of an El Niño event and a positive NPO event on the variability of wintertime precipitation.

The rest of this paper is organized as follows. Section 2 describes the data and methods. Section 3 presents the wintertime precipitation climatology and interannual variability over SC and the ECSK area. Section 4 investigates the synergistic effect of El Niño and positive NPO events on wintertime precipitation and its associated mechanisms. Section 5 presents conclusions and a discussion.

\section{Data and methods}

\subsection{TMPA}

The Tropical Rainfall Measuring Mission (TRMM) Multisatellite Precipitation Analysis (TMPA, https://storm.pps. eosdis.nasa.gov/storm/) combines precipitation estimates from multiple satellites on a $0.25^{\circ} \times 0.25^{\circ}$ grid (Huffman et al. 2007). It is capable of revealing the distribution of precipitation over SC and mid-latitude SST fronts in the 
Northern Hemisphere (Feng et al. 2017; O'Neill et al. 2017; Chen and Huang 2019; Sun et al. 2020). We use TMPA data from 1999 to 2019 to map the climatology and interannual variability of wintertime precipitation over SC and the ECSK area; the average value from December to February (DJF) is taken as the wintertime mean.

\subsection{ERA5}

The 10-m wind, horizontal wind, vertical motion, sea level pressure (SLP), SST, moisture flux and moisture convergence are taken from the ERA5 reanalysis data on a $0.25^{\circ} \times 0.25^{\circ}$ grid (Copernicus Climate Change Service 2017; Hersbach et al. 2018). The reanalysis precipitation, which is obtained from the forecast fields of ERA5, is used for composite analysis. Though the moisture field in the reanalysis data is unbalanced due to the uncertainties and continual changes in observations (Trenberth et al. 2011), the data from ERA5 appear to be reliable in analyzing frontal precipitation and the related atmospheric fields (Sun et al. 2020).

\subsection{Synergistic and antagonistic analysis}

To examine the combined effect of El Niño and NPO events on precipitation, we employ a $3 \times 3$ contingency table (Table 1) and the statistical diagnosis of synergistic or antagonistic effects proposed by Li et al. (2019). An ENSO or NPO event is identified when the corresponding index in DJF exceeds one half of its standard deviation. For two factors $\left(F_{1}\right.$ and $\left.F_{2}\right), F_{1} \backslash F_{2}$ and $\left|y_{1}\right|$ denote the case and the composite abnormal value when $F_{1}$ only happens without $F_{2} . F_{2} \backslash F_{1}$ and $\left|y_{2}\right|$ represent conditions when $F_{2}$ only happens without $F_{1} . F_{1} \oplus F_{2}$ and $\left|y_{12}\right|$ denote conditions when $F_{1}$ and $F_{2}$ happen simultaneously. The combined effect includes synergistic and antagonistic effects. A synergistic effect is an effect arising from two factors working together to produce an effect greater than each of their individual effects $\left(\left|y_{12}\right|>\max \left(\left|y_{1}\right|,\left|y_{2}\right|\right)\right)$. An antagonistic effect is an effect combining two factors that produces an effect less than each of their individual effects $\left(\left|y_{12}\right|<\min \left(\left|y_{1}\right|,\left|y_{2}\right|\right)\right)$. We estimate

Table 1 A $3 \times 3$ contingency table showing the frequency of ENSO and the NPO for the winters of 1980-2018 based on the DJF Niño 3.4 index and the NPO index in the previous winter

\begin{tabular}{lcccc}
\hline & $\mathrm{NPO}(-1)^{+}$ & $\mathrm{NPO}(-1)^{0}$ & $\mathrm{NPO}(-1)^{-}$ & Total \\
\hline El Niño & $\mathbf{6}$ & $\mathbf{5}$ & $\mathbf{2}$ & 13 \\
Neutral & $\mathbf{2}$ & 3 & 6 & 11 \\
La Niña & $\mathbf{4}$ & 5 & 6 & 15 \\
Total & $\mathbf{1 2}$ & 13 & 14 & 39 \\
\hline
\end{tabular}

The,+ 0 and - symbols represent positive, neutral, and negative NPO events, respectively. The bolded are conditions discussed in this study the synergistic and antagonistic effect on wind vectors by regarding $|y|$ as the corresponding anomalous wind speed.

\subsection{NPO index}

The effect of a positive NPO event on the subsequent winter El Niño event varies greatly due to different definitions of the NPO index (Chen and Wu 2018). Since the action centers of the NPO are unstable, Chen and $\mathrm{Wu}$ (2018) recommended a definition based on the empirical orthogonal function (EOF) technique. The second mode of North Pacific SLP describes the NPO pattern. Following Linkin and Nigam (2008), we regard the standardized second principal component (PC) of SLP from ERA5 over the North Pacific basin $\left(20^{\circ}-85^{\circ}\right.$ $\mathrm{N}, 120^{\circ} \mathrm{E}-120^{\circ} \mathrm{W}$ ) as the NPO index. The SLP anomalies for EOF are detrended and weighted by $(\cos \theta)^{1 / 2}$, where $\theta$ represents latitude, to account for the decrease of grid area toward the pole (Linkin and Nigam 2008). We obtain the wintertime Niño 3.4 index from the NCAR Climate Data Guide (https://climatedataguide.ucar.edu).

\subsection{Statistical methods}

We employ EOF analysis, composite analysis and correlation analysis in this study. A two-tailed $t$-test is used to obtain the statistical significance. To avoid the influences of autocorrelations, we use the effective degrees of freedom in the significance test (Pyper and Peterman 1998; Li et al. 2013).

\section{Wintertime precipitation}

\subsection{Climatology}

Figure 1a shows the observed wintertime climatology of precipitation. The maximum lies on the warm flank of the SST front over the ECSK region, reaching $6 \mathrm{~mm} \mathrm{day}^{-1}$. There is a second peak in SC, reaching $4 \mathrm{~mm} \mathrm{day}^{-1}$, located south of the Yangtze River. The ERA5 forecast data also reflect the detailed spatial structure of climatological precipitation except the additional peaks to the east of Taiwan island and a region $\left(110^{\circ} \mathrm{E}, 25^{\circ} \mathrm{N}\right)$ over the land (Fig. 1b). Note that the precipitation intensity east of Japan is more apparent than that over the SC and ECSK region (Fig. 1a, b). However, there is no evident interannual variability of precipitation over this region, so it is not considered further in this study.

\subsection{Interannual variation}

We examine the interannual variability of wintertime precipitation by calculating the standard deviation after removing the linear trend (Fig. 1c). A comparison between 

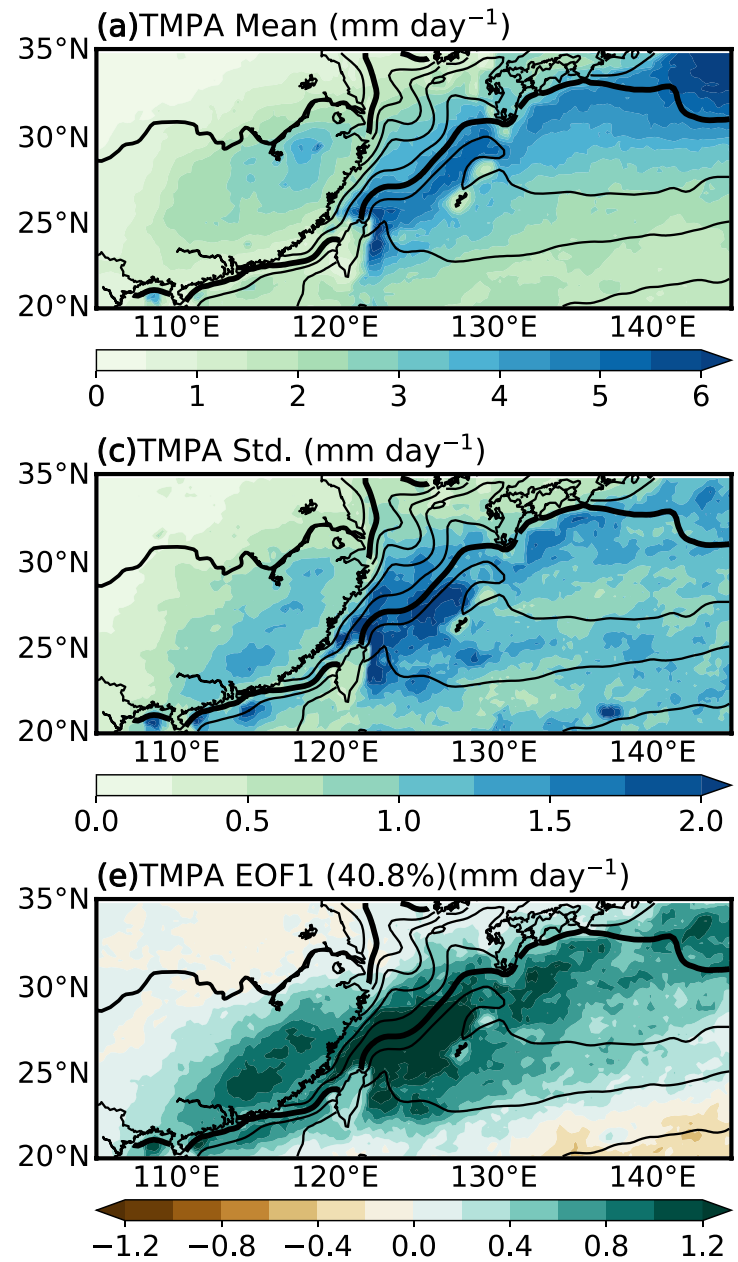

Fig. 1 Climatological means (a and $\mathbf{b}$, shaded, in $\mathrm{mm} \mathrm{day}^{-1}$ ), standard deviations (c and $\mathbf{d}$, shaded, in $\mathrm{mm} \mathrm{day}^{-1}$ ) on interannual timescales, and leading EOFs (e and $\mathbf{f}$, shaded, in $\mathrm{mm} \mathrm{day}^{-1}$ ) of DJF pre-

Fig. 1a, c shows that the magnitudes of precipitation variation over the SC and ECSK region are $30 \%$ of the DJF mean. The greatest variability on the land also lies to the south of the Yangtze River, but is farther south than the climatological peak. Over the ECSK region, the maximum of precipitation climatology lies over the warm flank of the SST front, while the interannual variability peak is right over the SST front.

EOF analysis is applied to the TMPA wintertime precipitation over $20^{\circ}-35^{\circ} \mathrm{N}, 107^{\circ}-145^{\circ} \mathrm{E}$ after removing the linear trend. The leading EOF (EOF1) is spatially uniform, explaining $40.8 \%$ of the variance. The EOF1 maximum covers the SC and ECSK region and has a similar pattern to the standard deviation (Fig. 1c, e). This suggests that EOF1 generally represents the precipitation variance over this area. The leading PC (PC1) is highly correlated with the time series of the averaged anomalous precipitation over $20^{\circ}-35^{\circ}$ $\mathrm{N}, 107^{\circ}-145^{\circ} \mathrm{E}$ with the correlation coefficient reaching 0.89 (solid lines in Fig. 2).
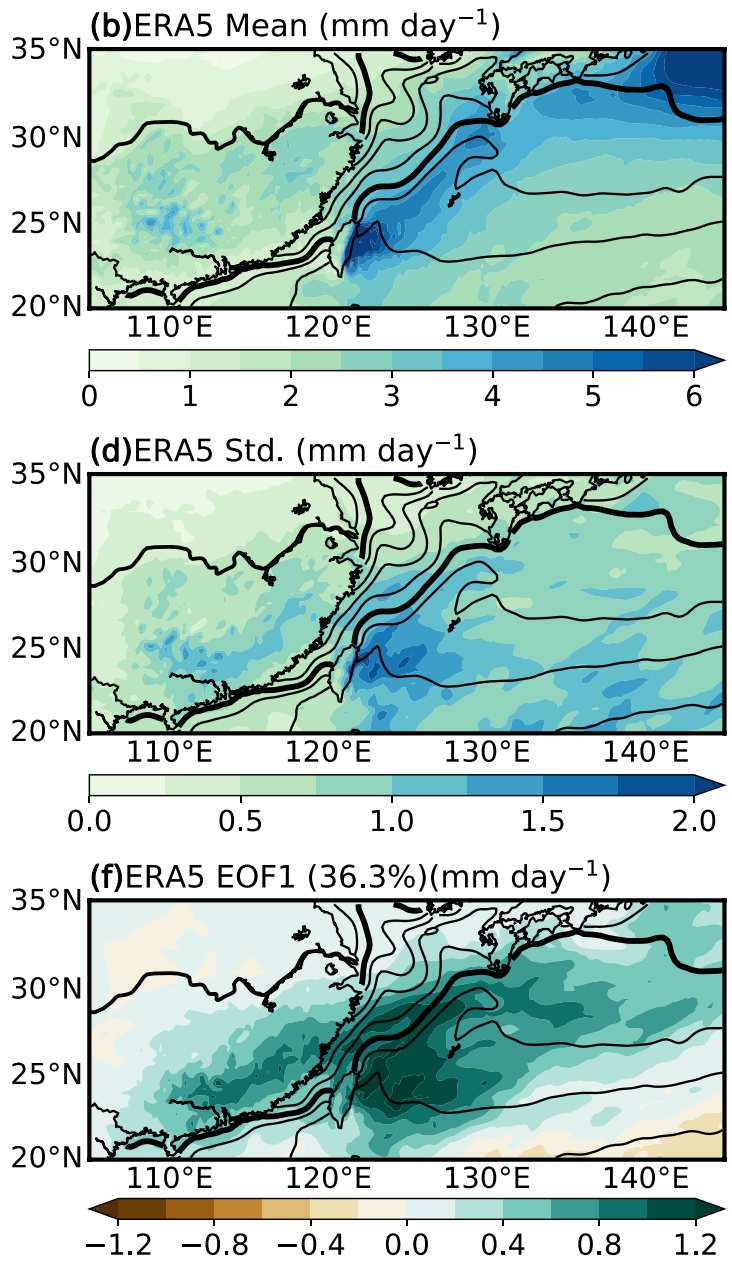

cipitation based on TMPA and ERA5, respectively. Here and in other figures, the black contours are the ERA5 DJF climatological SST at $2{ }^{\circ} \mathrm{C}$ intervals. Thick lines indicate the $10{ }^{\circ} \mathrm{C}$ and $20^{\circ} \mathrm{C}$ SST contours

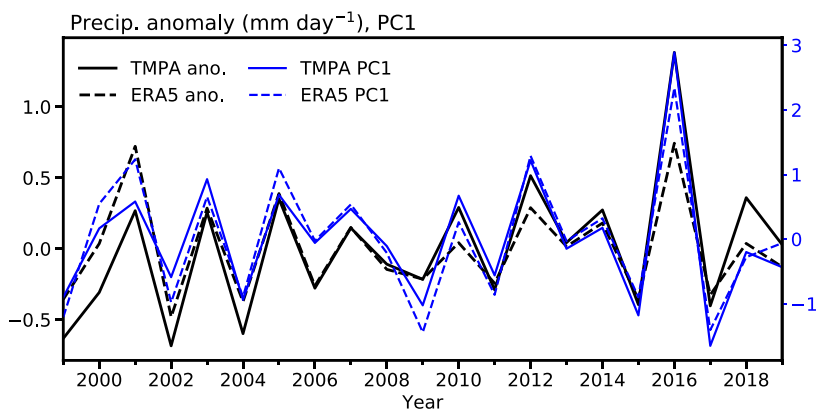

Fig. 2 Time series of DJF average precipitation anomalies (black lines in mm day ${ }^{-1}$ ) and standardized PC1 (blue lines) over $20^{\circ}-35^{\circ} \mathrm{N}$, $107^{\circ}-145^{\circ} \mathrm{E}$ based on TMPA (solid) and ERA5 (dashed)

ERA5 forecast data also effectively reveal the interannual variability of precipitation over this region. Figure $1 \mathrm{~d}$ shows the interannual standard deviation of DJF precipitation in ERA5. The distribution of standard deviation over 
the land is similar to that for TMPA (Fig. 1c, d). Over the ECSK region, the variability is also obvious over the SST front, but with a smaller magnitude than that of TMPA. The EOF1 of ERA5 precipitation explains $36.3 \%$ of the variance and resembles that of TMPA in spatial pattern. Most importantly, the correlation coefficient of precipitation anomalies in TMPA and ERA5 is 0.88 , and the PC1s of TPMA and ERA5 are highly correlated, with the correlation coefficient reaching 0.95 (Fig. 2). Since the TPMA dataset is not long enough for composite analysis, and ERA5 forecast precipitation can reproduce well the features of observed DJF precipitation both in the climatology and interannual variability, we employ ERA5 data from 1980 to 2018 for composite analysis in this study.

\subsection{Synergistic effect}

We employ composite analysis to investigate the joint effect of an El Niño event and a positive NPO event in the previous winter (hereafter referred to as an NPO event for short) on the wintertime precipitation over the SC and ECSK region. We classify winters from 1980 to 2018 into three categories based on the standardized Niño 3.4 index and NPO index in winter (Fig. 3). A joint event is when both El Niño and NPO events exist (El Niño $\oplus \mathrm{NPO}(-1))$. Here, $(-1)$ indicates the previous winter. In single-factor El Niño events an El Niño event happens without an NPO event (El NiñolNPO $(-1)$ ). In single-factor NPO events an NPO event happens without an El Niño event (NPO(-1)\El Niño). Table 2 lists winters

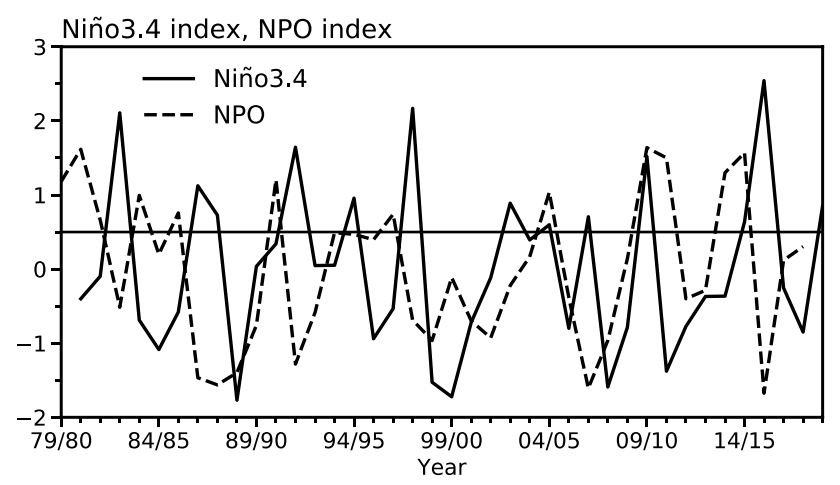

Fig. 3 Time series of DJF Niño 3.4 index (solid line) and NPO index (dashed line). The horizontal line is at 0.5 classified into these three categories according to Table 1. There are seven winters classified as $\operatorname{El} \operatorname{Niño} \operatorname{NPO}(-1)$, and six each for $\mathrm{NPO}(-1) \backslash \mathrm{El}$ Niño and $\mathrm{El}$ Niño $\oplus \mathrm{NPO}(-1)$. Note that the wintertime Niño 3.4 index from 1981 to 2018 is not significantly related to the previous winter NPO index, with a correlation coefficient of 0.28 .

Figure 4 shows the single and combined effects of an El Niño event and an NPO event on the DJF precipitation over the SC and ECSK area. Positive values $\left(\sim 0.5 \mathrm{~mm} \mathrm{day}^{-1}\right)$ of anomalous ERA5 precipitation extend continuously from the SC to the ECSK area under single-factor El Niño events (Fig. 4a). Figure $4 \mathrm{c}$ shows the composite wintertime precipitation anomalies under joint events, and positive precipitation anomalies are more apparent than in single-factor events. The positive values in Fig. $4 \mathrm{c}$ extend from $108^{\circ}$ to $145^{\circ} \mathrm{E}$, which resembles those of Fig. 4 a but with a much greater magnitude $\left(\sim 1.5 \mathrm{~mm} \mathrm{day}^{-1}\right)$. The enhanced precipitation in Fig. $4 \mathrm{c}$ results from the synergistic effect of the El Niño and NPO events (red grid lines in Fig. 4c) according to the definition of Li et al. (2019). The analysis of Fig. 4a, c reveals that an El Niño event without an NPO event intensifies wintertime precipitation over the SC and ECSK region, and this effect is triply enhanced when an El Niño event is accompanied by an NPO event. A comparison with the single-factor El Niño events, indicates that the additional increase of precipitation originates from the NPO event under joint event conditions.

A closer examination of Fig. $4 \mathrm{c}$ shows that the location of the anomalous precipitation band under joint events is farther south than under single-factor El Niño events. Moreover, precipitation anomalies are negative over the middle and lower reaches of the Yangtze River. The El Niño and NPO events have an antagonistic effect over this region (blue grid lines in Fig. 4c). This antagonistic effect is probably a result of the southward shift of the anomalous precipitation band compared with Fig. 4a and the negative anomalies of precipitation over the Yangtze River under single-factor NPO events (Fig. 4b). There is no obvious spatially uniform pattern of precipitation anomalies over our target region when there is an NPO event without an El Niño event (Fig. 4b).

Correlation analysis further verifies the synergistic effect between El Niño and NPO events on wintertime precipitation over the SC and ECSK region (Fig. 5). Note that the effective number of degrees of freedom is not used
Table 2 Winters classified into three categories according to Table 1

\begin{tabular}{ll}
\hline Category & Winter \\
\hline El NiñolNPO(-1) & $1987 / 88$ 1994/95 2002/03 2004/05 2006/07 2009/10 2018/19 \\
NPO(-1)\El Niño & $1980 / 81$ 1981/82 1984/85 2005/06 2010/11 2011/12 \\
El Niño $\oplus N P O(-1)$ & $\mathbf{1 9 8 2 / 8 3 ~ 1 9 8 6 / 8 7 ~ 1 9 9 1 / 9 2 ~ 1 9 9 7 / 9 8 ~ 2 0 1 4 / 1 5 ~ 2 0 1 5 / 1 6 ~}$ \\
\hline
\end{tabular}

El NiñolNPO(-1), NPO(-1)\El Niño, and El Niño $\oplus N P O(-1)$ indicate single-factor El Niño events, single-factor positive NPO events and joint events, respectively. The bolded indicates EP El Niño 

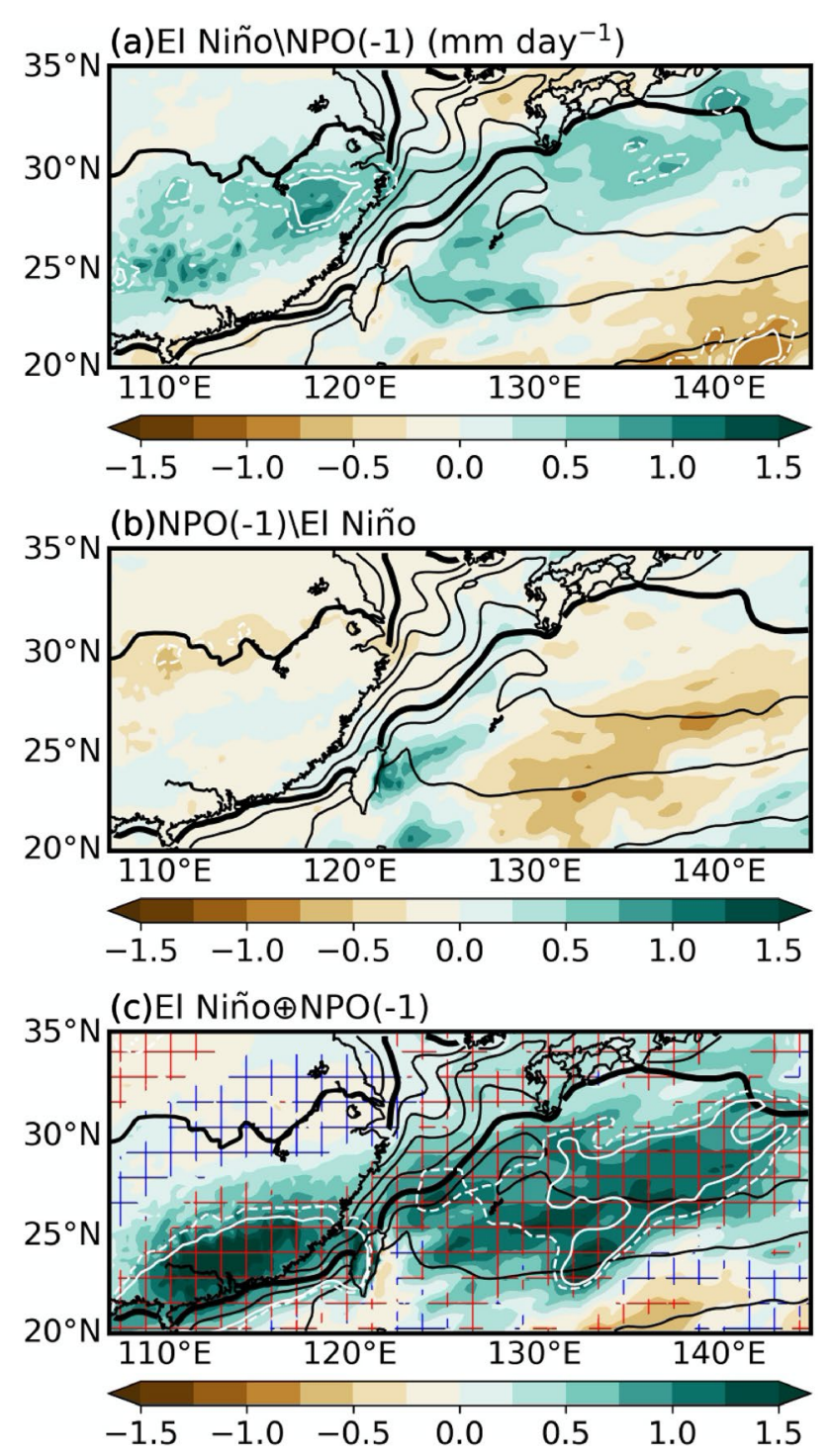

Fig. 4 Composite DJF precipitation anomalies (shaded, in $\mathrm{mm} \mathrm{day}^{-1}$ ) for the three categories in Table 2. a Single-factor El Niño events, b single-factor events of positive NPO in the previous winter, and c joint events. The grid lines in $\mathbf{c}$ indicate synergistic (red) or antagonistic (blue) effects on precipitation. The white solid (dashed) contour indicates the $95 \%$ (90\%) confidence level

for the significance test in this section because the years selected for correlation analysis are not continuous. For all El Niño events, the wintertime precipitation anomalies from 1980 to 2018 are significantly related to the Nino 3.4 index in both SC and the ECSK area (Fig. 5a). When an El Niño event occurs without an NPO event, the Nino 3.4 index is positively correlated with the precipitation over SC but over a more limited area of significance, and the correlation becomes negative over the ECSK area (Fig. 5b). When an El Niño event coexists with an NPO event, the correlation coefficients are significant over both SC and the ECSK area (Fig. 5c). This means that an El Niño event has a clear relationship with the precipitation anomalies over SC and the ECSK area (Fig. 5a). The linkage mainly results from the years when both El Niño and NPO events happen, especially over the ECSK area (Fig. 5c). Taking both El Niño and NPO events into consideration when analyzing and predicting the wintertime precipitation over the SC and ECSK area makes sense.

\section{Synergistic effect between El Niño and NPO on wintertime precipitation and its associated mechanisms}

\subsection{Atmospheric circulation and moisture conditions}

We investigate the anomalous atmospheric circulation related to the enhanced wintertime precipitation under both single-factor El Niño and joint events. When an El Niño event occurs without an NPO event, southeasterlies and southwesterlies prevail over the SC and ECSK area at $700 \mathrm{hPa}$ and $500 \mathrm{hPa}$ (Fig. 6a, c), respectively. The pattern of upward motion at $700 \mathrm{hPa}$ resembles that of anomalous precipitation (Figs. 4a, 6c). The distribution of upward motion anomaly at $500 \mathrm{hPa}$ is similar to that at $700 \mathrm{hPa}$, but with a slight northward shift (Fig. 6a).

Upward motion influenced by joint events also has similar patterns to the corresponding anomalous precipitation (Fig. 6b, d). The El Niño and NPO events enhance the upward motion synergistically at both 700 and $500 \mathrm{hPa}$ (red grid lines in Fig. 6b, d). Southeasterlies occupy our target area, and almost all of the wind vectors are synergistically influenced by joint events (red vectors in Fig. 6b, d). The horizontal winds are accelerated with cyclonic circulation at 700 and $500 \mathrm{hPa}$, contributing to the moisture advection and convergence over our target area.

Under single-factor El Niño events, the northeastward moisture flux in Fig. 7a indicates that adequate water vapor for precipitation over SC and the ECSK area comes from the South China Sea and warm flank of the Kuroshio SST front, respectively (Fig. 7a). The synergistic effect of northeastward moisture flux under joint events is obvious over our target area (red vectors in Fig. 7b). Spatial patterns of vertically integrated moisture convergence under both single-factor El Niño and joint events resemble those of enhanced precipitation (Figs. 4, 7). Thus, the NPO event adds additional precipitation via intensified upward motion, cyclonic circulation, northeastward moisture flux and vertical integrated moisture convergence. 
Fig. 5 a Correlation coefficients (shaded) between DJF precipitation anomalies and Niño 3.4 index for all El Niño events. b As in a but for single-factor El Niño events. $\mathbf{c}$ As in a but for joint events. Dots indicate statistical significance at the $95 \%$ confidence level
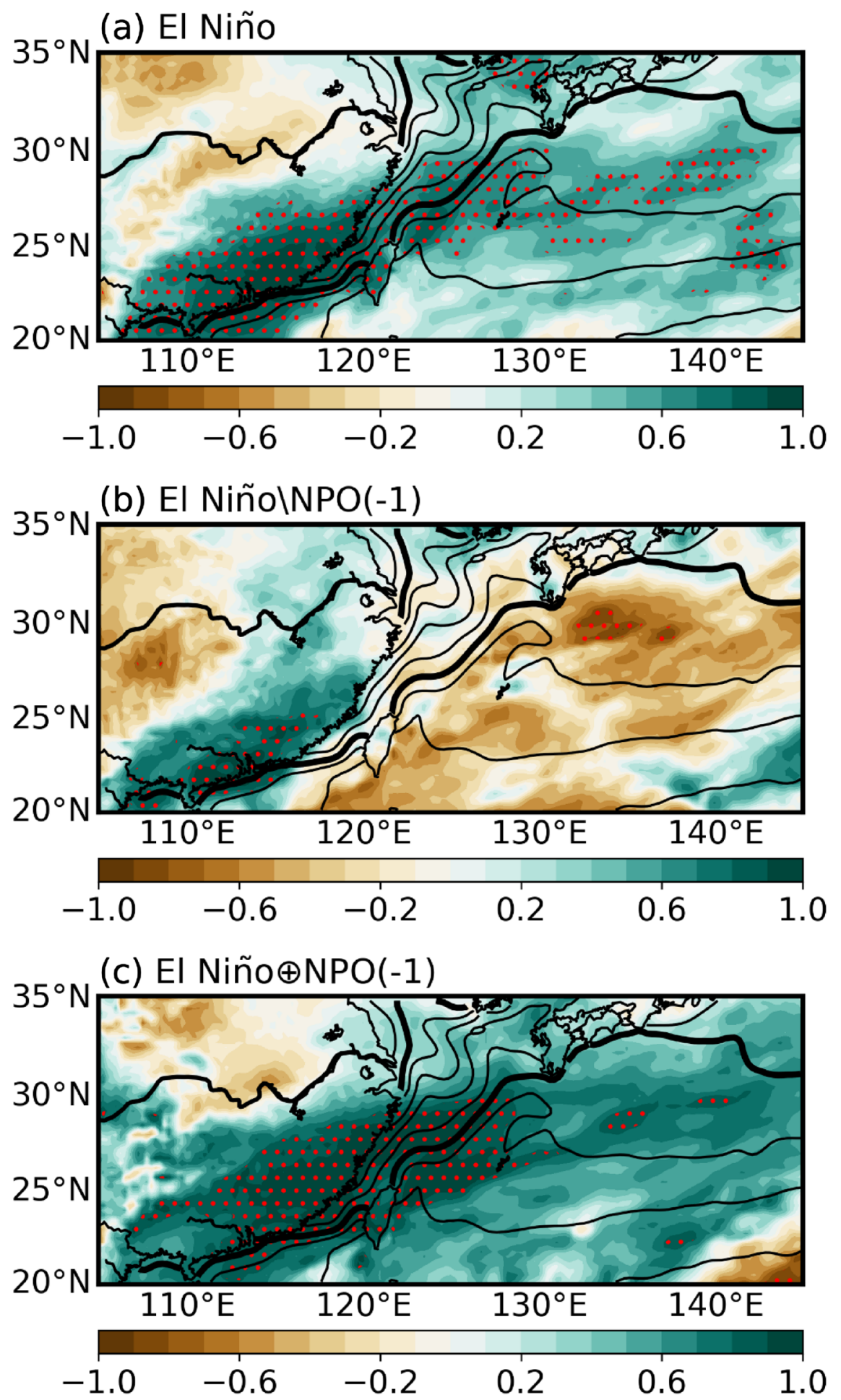

\subsection{Effect of the positive NPO event in the previous winter on El Niño}

To clarify the relationship between NPO and El Niño events, we examine the evolution of seasonally averaged anomalies of SST and surface atmospheric circulation under joint events from the previous winter $\operatorname{DJF}(-1)$ to the current winter $\operatorname{DJF}(0)$. The results in Fig. 8 resemble the conclusions of Ding et al. $(2015,2018)$. A meridional tripole-like SST anomaly pattern is clearly seen in the North Pacific (Fig. 8a), which closely resembles the spatial pattern of the positive VM (Bond et al. 2003). An anomalous positive SST band extends from off California to the western Bering Sea, and an anomalous negative SST band extends from the center of 


\section{$500 \mathrm{hPa}$}
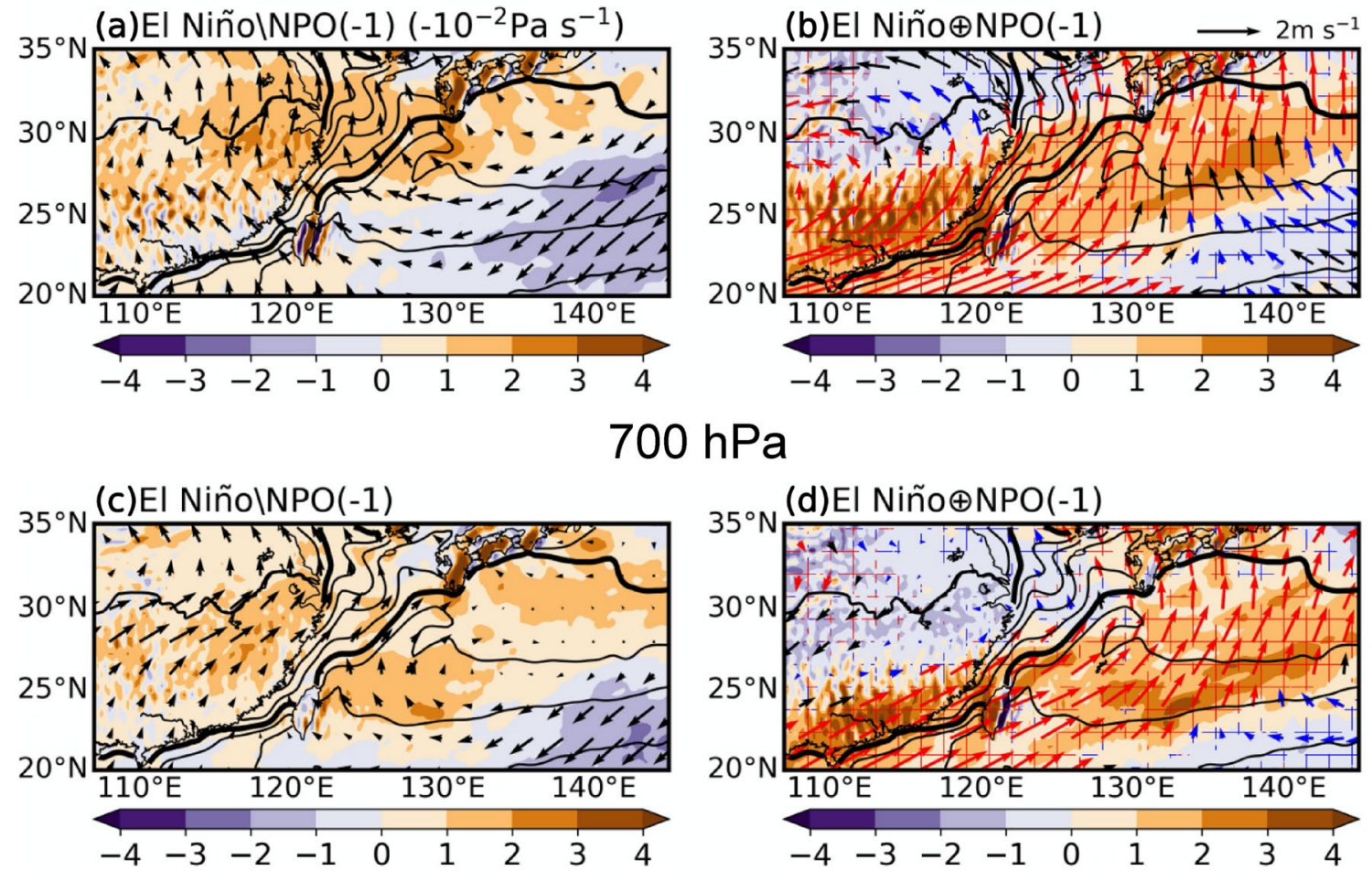

Fig. 6 Composite DJF upward motion anomalies (shaded, in $-10^{-2} \mathrm{~Pa} \mathrm{~s}^{-1}$ ) and anomalous horizontal wind velocities (vectors, in $\left.\mathrm{m} \mathrm{s}^{-1}\right)$ at $500 \mathrm{hPa}(\mathbf{a}, \mathbf{b})$ and $700 \mathrm{hPa}(\mathbf{c}, \mathbf{d})$. a and c represent single-factor El Niño events. $\mathbf{b}$ and $\mathbf{d}$ represent joint events with

the gridded areas and colored vectors indicating synergistic (red) or antagonistic effect (blue) on upward motion and horizonal wind, respectively

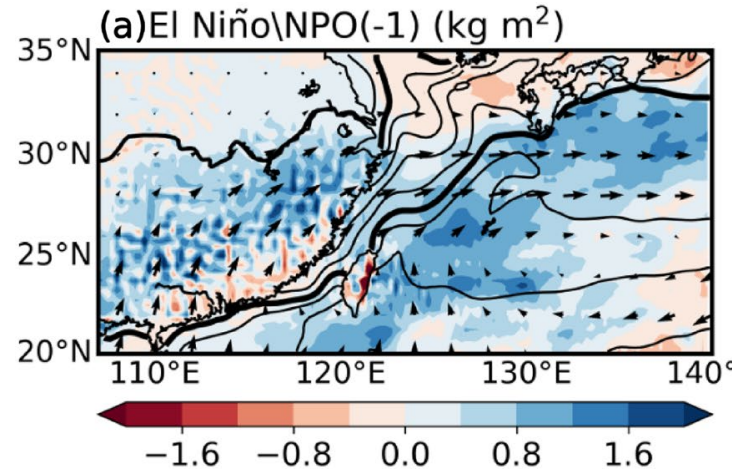

Fig. 7 Same as Fig. 6, but for anomalous vertically integrated moisture convergence (shaded, in $\mathrm{kg} \mathrm{m}^{2}$ ) and moisture flux (vectors, in $20 \mathrm{~kg} \mathrm{~m}^{-2} \mathrm{~s}^{-1}$ ) with the gridded areas and colored vectors indicat-

the North Pacific to the coast of Asia. So the positive VM appears with an anomalous circulation resembling the positive NPO during the previous winter $\operatorname{DJF}(-1)$. Figure $8 \mathrm{~b}$ shows that the VM continues into spring $\operatorname{MAM}(0)$, and the NPO-related atmospheric circulation almost disappears. Meanwhile, the warmer SST band in the eastern subtropical North Pacific extends toward the central and eastern

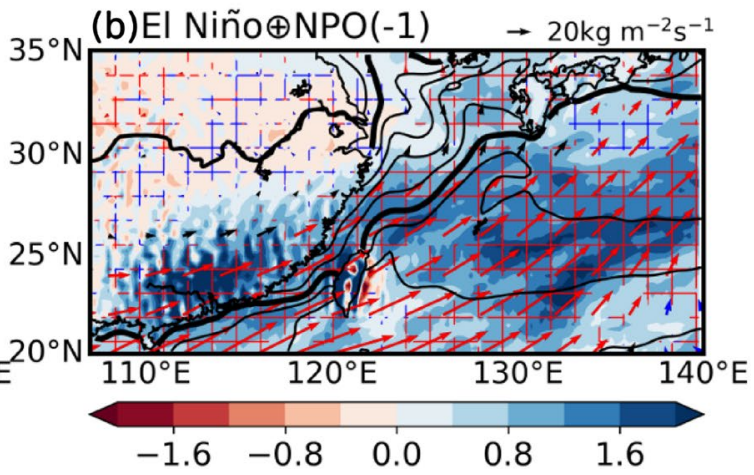

ing synergistic (red) or antagonistic (blue) effects on moisture convergence and flux, respectively

equatorial Pacific. Anomalous atmospheric circulation associated with the VM also extends to the entire equatorial Pacific (Fig. 8b). Low pressure anomalies occur over the subtropical North Pacific (contours in Fig. 8b), inducing anomalous westerly winds in the western equatorial Pacific.

Westerly anomalies and southeasterlies in the tropical eastern Pacific induce convergence in the central 

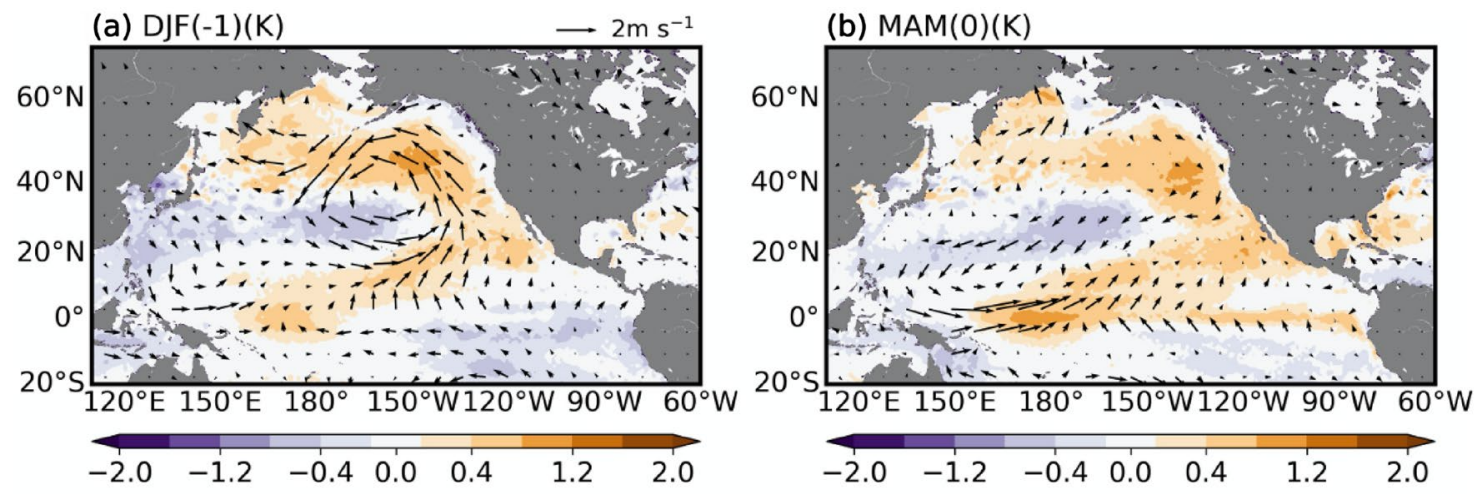

(c) $\mathrm{JJA}(0)(\mathrm{K})$

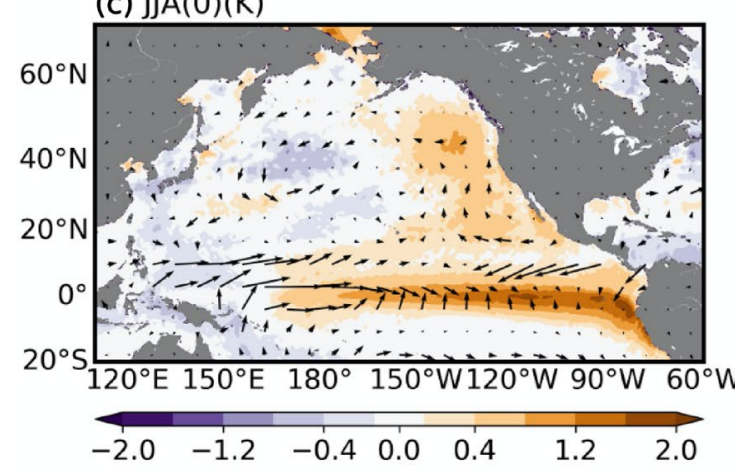

(d) $\operatorname{SON}(0)(K)$

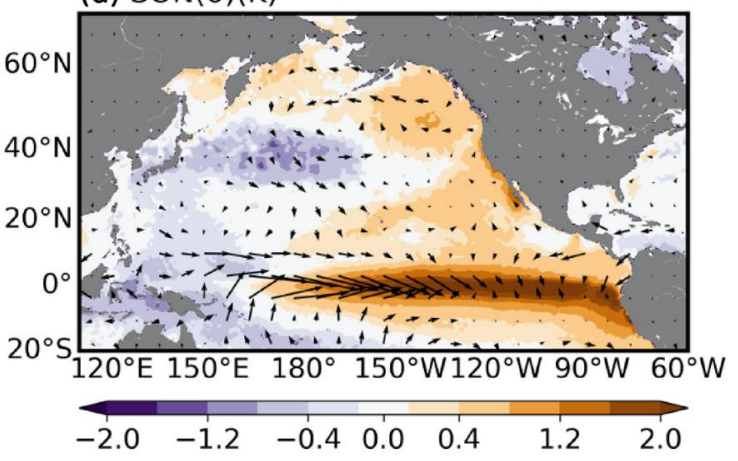

(e) $\mathrm{DJF}(0)(\mathrm{K})$

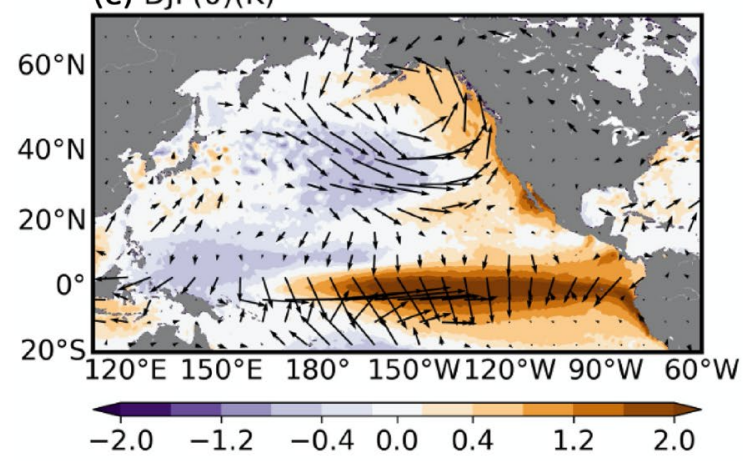

(f) $\mathrm{DJF}(0)$ El Niño $\oplus \mathrm{NPO}(-1)$-El NiñolNPO(-1)

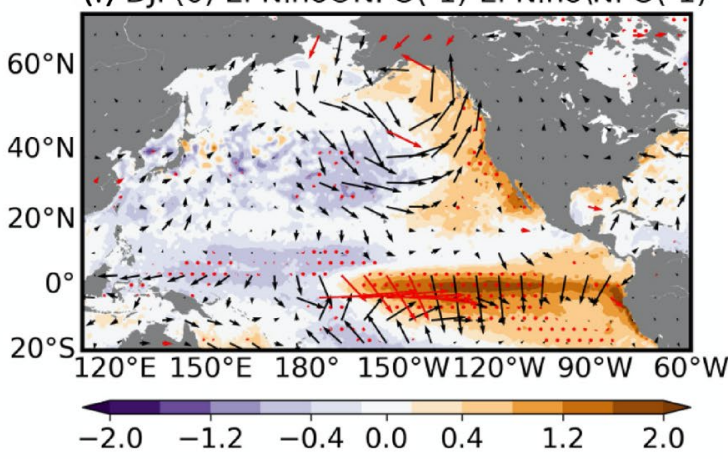

Fig. 8 Composite anomalies of SST (shaded, in K) and 10-m wind (vectors, in $\mathrm{m} \mathrm{s}^{-1}$ ) under joint events. a Previous winter. b Spring. Dashed contours at $0.2 \mathrm{hPa}$ intervals indicate anomalously low sea level pressure. c Summer, d Autumn, e Winter. $\mathbf{f}$ is the difference

between single-factor El Niño and joint events in winter. The dotted areas and red vectors indicate statistical significance at the $95 \%$ confidence level based on the Student $t$-test

equatorial Pacific and in turn favor the development there of positive SST anomalies (Fig. 8b). The positive feedback of air-sea interaction in turn amplifies the zonal wind and SST anomalies along the equator (Bjerknes 1969), driving the development of El Niño from summer to autumn (Fig. 8c, d). During DJF(0), 1 year after the NPO event, a warming SST pattern is well developed in the eastern equatorial Pacific (Fig. 8e). The central to eastern equatorial Pacific under joint events is significantly warmer than under single-factor El Niño events (Fig. 8f). The positive NPO event enhances the El Niño intensity via the ocean

bridge of VM and the resulting anomalous Bjerknes feedback. The mean Niño 3.4 index of single-factor El Niño events and joints events are 0.9 and 1.73 , respectively.

Note that the relationship between positive NPO event and El Niño intensity still works during 1949-1979. We calculate the NPO index from National Centers for Environmental Prediction (NCEP), and check the relationship between El Niño intensity and positive NPO event for the period of 1949-1979 (Table 3). The mean Niño 3.4 index of single-factor El Niño events and joints events are 0.81 and 1.35 , which verifies the robustness of this relationship. 
Table 3 Winters of single-factor El Niño events and joint events for the period of 1949-1979 based on the DJF Niño 3.4 index and the NPO index in the previous winter

\begin{tabular}{lcc}
\hline Category & Winter & Niño 3.4 index \\
\hline El NiñolNPO(-1) & $1953 / 54,1958 / 59,1969 / 70,1972 / 73,1976 / 77$, & $0.8,0.6,0.5$, \\
& $1977 / 78,1979 / 80$ & $1.8,0.7,0.7$, \\
El Niño $\oplus \mathrm{NPO}(-1)$ & $1957 / 58,1963 / 64,1965 / 66,1968 / 69$ & 0.6 \\
\hline
\end{tabular}

\subsection{Weakened Walker cell and regional Hadley cell}

The zonal SST contrast in the equatorial Pacific is closely related to the thermally driven Walker cell (Bjerknes 1969). Walker circulation variability is associated with the interannual phenomenon of El Niño (e.g., Philander 1990; McCreary and Anderson 1991). We examine the wintertime Walker cell in terms of the zonal-vertical circulation $\left(\mathrm{u}\right.$ and $-\omega$ ) averaged between $5^{\circ} \mathrm{S}$ and $5^{\circ} \mathrm{N}$. Figure 9 a shows that the climatological wintertime Walker circulation cell is characterized by ascending motion in the equatorial western Pacific, eastward flow in the upper troposphere, downward motion in the equatorial eastern Pacific, and flow toward the equatorial western Pacific in the lower troposphere (Walker 1923, 1925; Bjerknes 1969).

Under single-factor El Niño events, anomalous upward motion dominates the troposphere from $170^{\circ} \mathrm{E}$ to $150^{\circ}$ $\mathrm{W}$, with the largest anomaly located over the central tropical Pacific (Fig. 9b). Meanwhile, downward motion anomalies appear in the entire troposphere from $120^{\circ}$ to $150^{\circ} \mathrm{E}$. Under joint events, anomalous ascending motion is strengthened from $170^{\circ} \mathrm{E}$ to $90^{\circ} \mathrm{W}$, and the largest anomaly also lies on the central tropical Pacific (Fig. 9c). The descending motion from $120^{\circ}$ to $150^{\circ} \mathrm{E}$ is also more apparent than in single-factor El Niño events. The El Niño and NPO events have a synergistic effect on reversing the zonal-vertical circulation (red vectors in Fig. 9c). Thus, both the intensified upward motion over the central to eastern tropical Pacific and the anomalous downward motion over the western tropical Pacific are especially remarkable when the wintertime El Niño event follows an NPO event.

To depict simply the intensity of the Walker circulation, we define the zonal-vertical circulation index as the difference of zonal wind between 200 and $850 \mathrm{hPa}$ $\left(\mathrm{U}_{200}-\mathrm{U}_{850}\right)$, with a positive (negative) value indicating intensified (weakened) Walker circulation. The anomalous Walker cell indexes under single-factor El Niño and joint events are negative over the tropical Pacific, indicative of weakened Walker cells (Fig. 10a, b). When the El Niño event is accompanied by an NPO event, the El Niño intensity is enhanced and the Walker circulation weakens by a larger magnitude over the central and eastern tropical Pacific (Fig. 10d).

The Hadley circulation cell, located in the tropics and subtropics, is also thermally forced. Heated tropical air rises and flows aloft toward the subtropics, where it cools, sinks, and flows back to the tropics (Trenberth et al. 2000). The wintertime meridional-vertical circulation $(\mathrm{v}$ and $-\omega)$ averaged between $110^{\circ}$ and $140^{\circ} \mathrm{E}$ over the northwestern Pacific has a similar pattern to the typical Hadley circulation (Fig. 11a). When a wintertime El Niño event occurs without an NPO event, the anomalous meridionalvertical circulation is characterized by downward and upward motion over $0^{\circ}-15^{\circ} \mathrm{N}$ and $25^{\circ}-35^{\circ} \mathrm{N}$, respectively (Fig. 11b). Under joint events there is a similar pattern, but with a larger magnitude and a more southerly location (Fig. 11c). The greater weakening of the Walker circulation (Fig. 9c) indicates that the El Niño event and NPO
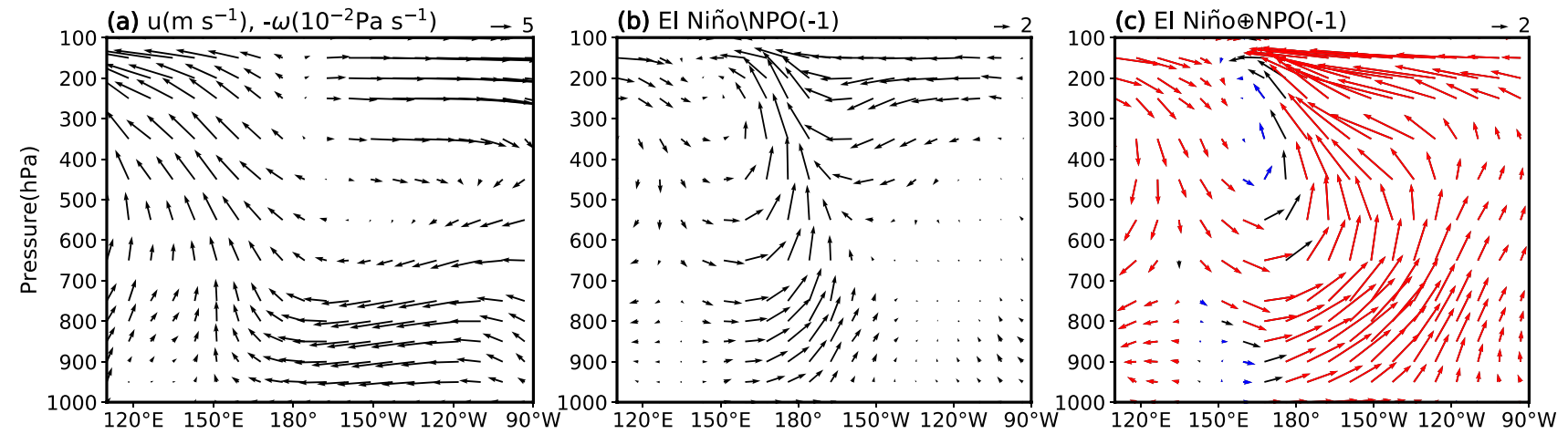

Fig. 9 Zonal-vertical circulation showing DJF u (in $\mathrm{m} \mathrm{s}^{-1}$ ) and $-\omega$ (in $10^{-2} \mathrm{~Pa} \mathrm{~s}^{-1}$ ) between $5^{\circ} \mathrm{S}$ and $5^{\circ} \mathrm{N}$, with leftward and upward arrows indicating easterly and upward motion, respectively. a DJF climatol- ogy, b composite anomalies under single-factor El Niño events, and c joint events. The colored vectors in $\mathbf{c}$ indicate synergistic (red) or antagonistic (blue) effects on the circulation 
(a) El NiñolNPO(-1)

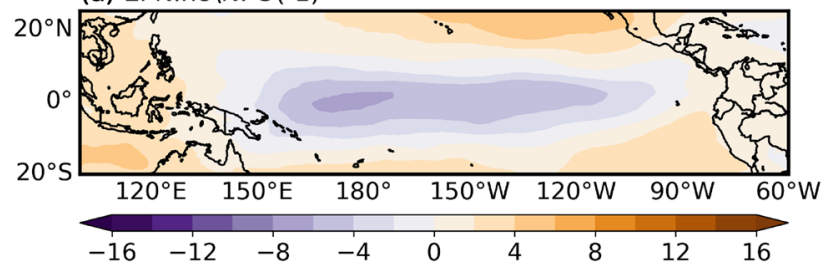

(b) El Niño $\oplus \mathrm{NPO}(-1)$

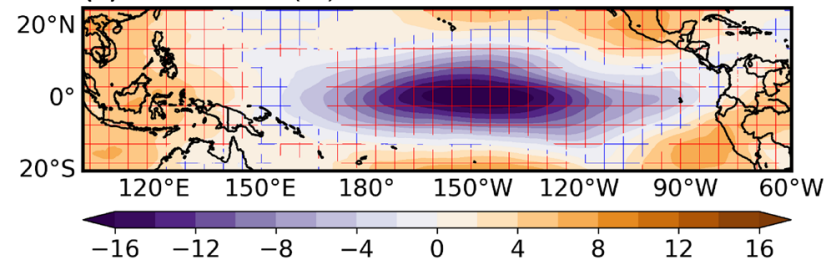

Fig. 10 Composite anomalies of DJF zonal-vertical circulation index under a single-factor El Niño events and $\mathbf{b}$ joint events. The grid lines in b indicate a synergistic (red) or antagonistic effect (blue) on the circulation index

event also have a synergistic effect on reversing the zonalvertical circulation (red vectors in Fig. 11c).

Similarly, we define the regional meridional-vertical circulation index as the difference of meridional wind between 200 and $850 \mathrm{hPa}\left(\mathrm{V}_{200}-\mathrm{V}_{850}\right)$, with the positive (negative) values indicating intensified (weakened) regional Hadley circulation. The anomalous meridional-vertical circulation indexes of single-factor El Niño and joint events are negative over the South China Sea, indicative of weakened regional Hadley cells (Fig. 12a, b). The anomalous regional Hadley circulation under joint events is weaker than under singlefactor El Niño events due to the correspondingly much weaker Walker circulation (Fig. 10d).

Under single-factor El Niño events, warmer SST over the central to eastern tropical Pacific and colder SST over the western tropical Pacific induce a reversed Walker circulation, with anomalous descending motion over the western tropical Pacific. The anomalous descending motion then triggers a reversed regional Hadley circulation over the northwestern Pacific. The reversed regional Hadley cell has downward motion over the Philippine Islands and upward motion over the SC and ECSK region (Figs. 6, 11). Moreover, the enhanced low-level northeastward flow of the reversed regional Hadley cell transports more water vapor to the SC and ECSK region (Figs. 7, 11). More precipitation then falls over the SC and ECSK region owing to the anomalous upward motion and moisture induced by the weakened regional Hadley circulation. The NPO event largely facilitates the above process by intensifying the El Niño event, which results in a much weaker Walker cell, a much weaker Hadley cell, and more precipitation over the SC and ECSK region.

\section{Conclusions and discussion}

Wintertime precipitation in China is most pronounced over SC, and the Kuroshio in the East China Sea anchors a prominent precipitation band over the warm side of the SST front. Previous studies have suggested that many single factors are responsible for interannual variation of the precipitation intensity over SC, whereas less attention has been paid to the precipitation variability over the ECSK area at interannual timescale. This study focuses on the interannual variation of precipitation over the SC and ECSK region from the perspective of joint effect. The results show that the wintertime precipitation exhibits strong variability over both $\mathrm{SC}$ and the ECSK SST front.

EOF analysis is applied to analyze the interannual variation of precipitation over the SC and ECSK region. EOF1s based on TMPA and ERA5 depict the characteristics of precipitation variation over our target area, and have synchronous and spatially uniform patterns from SC to the ECSK area (Figs. 1, 2). Composite analysis shows that an El Niño
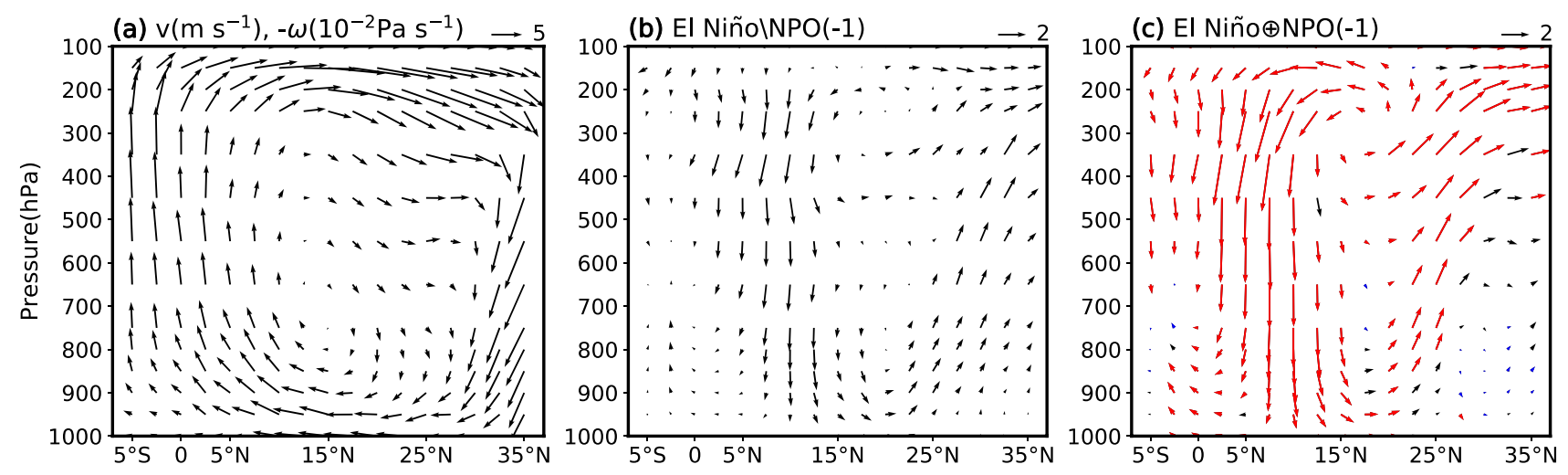

Fig. 11 Same as Fig. 9, but for meridional-vertical circulation with DJF v (in m s${ }^{-1}$ ) and $-\omega\left(\right.$ in $10^{-2} \mathrm{~Pa} \mathrm{~s}^{-1}$ ) averaged between $110^{\circ}$ and $140^{\circ} \mathrm{E}$, with leftward and upward arrows indicating northerly and upward motion, respectively 
Fig. 12 Same as Fig. 10, but for the meridional-vertical circulation index

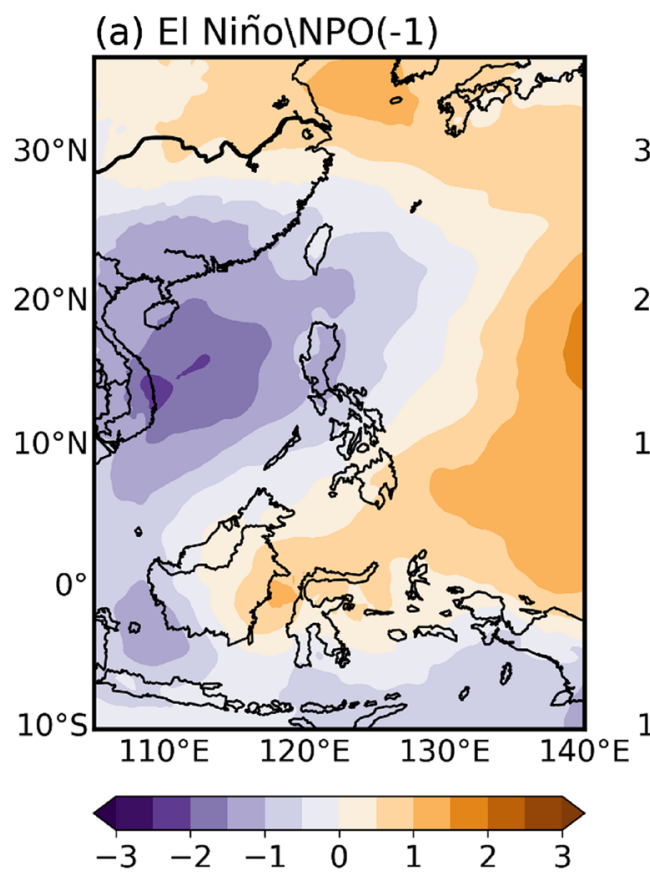

(b) El Niño $\oplus \mathrm{NPO}(-1)$

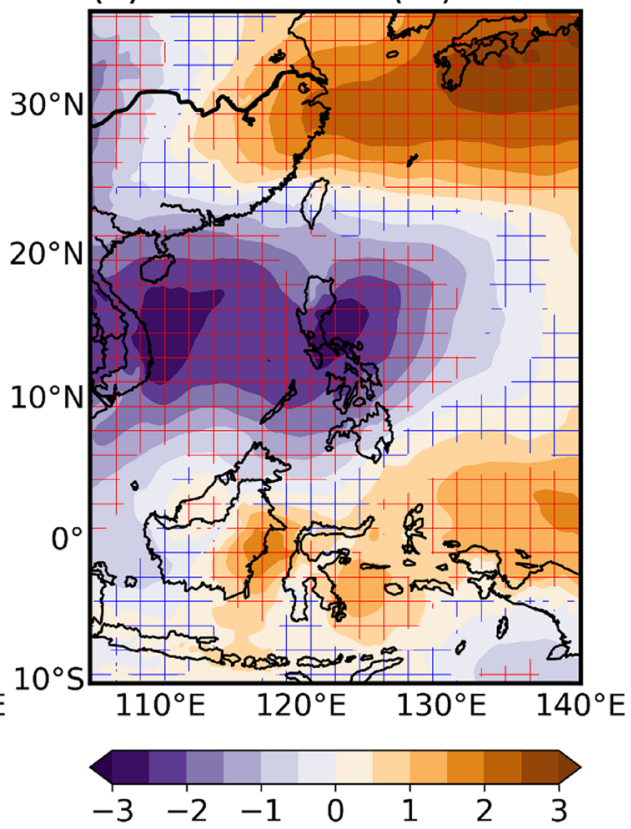

event intensifies wintertime precipitation over the SC and ECSK region, and this effect is tripled when an El Niño event coexists with a positive NPO event in the previous winter (Fig. 4). This means that El Niño and NPO events have a synergistic effect on the enhancement of wintertime precipitation over the SC and ECSK region.

We reveal how the precipitation is intensified under joint events from the perspective of dynamics and moisture conditions. The results show that compared with single-factor El Niño events, the additional anomalous upward motion, cyclonic circulation (Fig. 6), northeastward moisture flux and vertical integrated moisture convergence (Fig. 7) over the SC and ECSK region originate from the NPO event. The additional upward motion and northeastward flow result from a more significantly weakened regional Hadley cell over the northwestern Pacific.

Then, we interpret the linkage between the NPO event and the significantly weakened Hadley cell. The regional Hadley circulation is associated with the Walker cell, which is thermally forced by the zonal SST contrast in the equatorial Pacific Ocean (Bjerknes 1969). Single-factor El Niño events weaken the Walker circulation by reducing the equatorial Pacific SST gradient (Figs. 9, 10). The weakened Walker circulation has anomalous descending motion over the western tropical Pacific, which triggers a reversed regional Hadley circulation over the northwestern Pacific (Figs. 11, 12). Under joint events, the NPO event intensifies the existing El Niño event, and results in a much weaker Walker cell than with the single-factor event of El Niño. The much weaker Walker cell then triggers a much weaker regional Hadley cell through descending motion over the western tropical Pacific. The greatly reduced Hadley circulation directly enhances the wintertime precipitation over the SC and ECSK region.

To verify the intensification of an El Niño event by an NPO event, we examine the evolution of seasonally averaged anomalies of SST and surface atmospheric circulation under joint events from the previous winter $\operatorname{DJF}(-1)$ to winter DJF(0) (Fig. 8). A positive VM forms in the North Pacific with an anomalous circulation resembling the NPO developing during the previous winter $\operatorname{DJF}(-1)$. A warmer SST band and corresponding atmospheric circulation anomalies in the eastern subtropical North Pacific extend toward the central and eastern equatorial Pacific in boreal spring. The sea level pressure is then anomalously low over the subtropical North Pacific in summer, inducing anomalous westerly winds in the western equatorial Pacific. Westerly anomalies induce convergence in the central equatorial Pacific and help to develop the higher SST there. Positive feedback from air-sea interaction amplifies the zonal wind and SST anomalies over the equator (Bjerknes 1969), driving the development of El Niño. In comparison with single-factor El Niño events, the central to eastern equatorial Pacific is much warmer under joint events (Fig. 8f). Thus, the positive NPO event in the previous winter enhances the El Niño intensity via the VM ocean bridge and the subsequent anomalous Bjerknes feedback.

Since the extratropical circulation that roots from the tropical Pacific not only depends on the El Niño intensity but also its spatial diversity (Zhang et al. 2019a, b; Zhang and $\mathrm{Wu} 2021$ ). We further examine the anomalous SST distributions of single-factor El Niño events and joint events, and 
find that the spatial diversity of El Niño events also works. According to the method of Ren and Jin (2011), we divided the El Niño events into eastern-Pacific (EP) El Niño and central-Pacific (CP) El Niño based on the warm-pool index and cold-tongue index. Six out of seven El Niño events are CP types under single-factor El Niño events, and five out of six El Niño events are EP types under joint events (Table 2). This indicates that a wintertime strong positive NPO event favors a strong EP El Niño event a year later. The El Niño diversity can explain the phenomenon that the location of the anomalous precipitation band under joint events is farther south than under single-factor El Niño events (Fig. 4). This coincides with the result of Wang et al. (2019) that the precipitation influenced by $\mathrm{CP} \mathrm{El}$ Niño is farther north than that influenced by EP El Niño. The relationship between positive NPO event and El Niño diversity still needs further investigation.

This study indicates that a positive NPO event in the previous winter favors the development of a wintertime $\mathrm{El}$ Niño event, which is the most prominent air-sea interaction phenomenon over the tropical Pacific Ocean at interannual timescales. El Niño events have remarkable influences on global weather and climate, agriculture, and human health (Hansen et al. 1998; Chiang and Sobel 2002; Kovats et al. 2003; McGregor and Ebi 2018). The synergistic effect of an El Niño and an NPO event in this study indicates that the influences of the El Niño event are amplified by the NPO event. The linkage between a positive NPO event in the previous winter and the additional influence on precipitation offers the possibility of improvement of prediction skill.

Acknowledgements This work was jointly sponsored by Shandong Natural Science Foundation Project (ZR2019ZD12), National Natural Science Foundation of China (NSFC) Project (41790474) and Fundamental Research Funds for the Central Universities (201962009). We appreciate two anonymous reviewers for their insightful and constructive comments. We obtained the data from the NASA Goddard Space Flight Center's Mesoscale Atmospheric Processes Laboratory and Precipitation Processing System (TMPA), the ECMWF data server (ERA5) and he Climate Data Guide of NCAR (Niño 3.4 index).

Open Access This article is licensed under a Creative Commons Attribution 4.0 International License, which permits use, sharing, adaptation, distribution and reproduction in any medium or format, as long as you give appropriate credit to the original author(s) and the source, provide a link to the Creative Commons licence, and indicate if changes were made. The images or other third party material in this article are included in the article's Creative Commons licence, unless indicated otherwise in a credit line to the material. If material is not included in the article's Creative Commons licence and your intended use is not permitted by statutory regulation or exceeds the permitted use, you will need to obtain permission directly from the copyright holder. To view a copy of this licence, visit http://creativecommons.org/licenses/by/4.0/.

\section{References}

Alexander LV, Zhang X, Peterson TC, Caesar J, Gleason B, Klein Tank A, Haylock M, Collins D, Trewin B, Rahimzadeh F (2006) Global observed changes in daily climate extremes of temperature and precipitation. J Geophys Res Atmos 111:D05109. https://doi.org/ 10.1029/2005JD006290

Alexander MA, Vimont DJ, Chang P, Scott JD (2010) The impact of extratropical atmospheric variability on ENSO: testing the seasonal footprinting mechanism using coupled model experiments. J Clim 23:2885-2901

Anderson BT (2007) On the joint role of subtropical atmospheric variability and equatorial subsurface heat content anomalies in initiating the onset of ENSO events. J Clim 20:1593-1599

Bjerknes J (1969) Atmospheric teleconnections from the equatorial Pacific. Mon Weather Rev 97:163-172

Bond NA, Overland JE, Spillane M, Stabeno P (2003) Recent shifts in the state of the North Pacific. Geophys Res Lett 30:2183

Chen F, Huang H (2019) Comparisons of gauge, TMPA and IMERG products for monsoon and tropical cyclone precipitation in Southern China. Pure Appl Geophys 176:1767-1784. https://doi.org/10. 1007/s00024-018-2038-z

Chen S, Wu R (2018) Impacts of winter NPO on subsequent winter ENSO: sensitivity to the definition of NPO index. Clim Dyn 50:375-389. https://doi.org/10.1007/s00382-017-3615-z

Chen F, Chen Q, Hu H, Fang J, Bai H (2020) Synergistic effects of midlatitude atmospheric upstream disturbances and oceanic subtropical front intensity variability on western Pacific jet stream in winter. J Geophys Res 125:e2020JD032788. https://doi.org/10. 1029/2020JD032788

Chiang JCH, Sobel AH (2002) Tropical tropospheric temperature variations caused by ENSO and their influence on the remote tropical climate. J Clim 15:2616-2631

Copernicus Climate Change Service (2017) ERA5: Fifth generation of ECMWF atmospheric reanalysis of the global climate. Copernicus Climate Change Service Climate Data Store

Dai A, Wigley T (2000) Global patterns of ENSO-induced precipitation. Geophys Res Lett 27:1283-1286

Ding R, Li J, Tseng YH, Sun C, Guo Y (2015) The Victoria mode in the North Pacific linking extratropical sea level pressure variations to ENSO. J Geophys Res Atmos 120:27-45

Ding RQ, Li J, Tseng YH, Sun C, Xie F (2017) Joint impact of North and South Pacific extratropical atmospheric variability on the onset of ENSO events. J Geophys Res Atmos 122:279-298

Ding R, Li J, Tseng YH, Li LJ, Sun C, Xie F (2018) Influences of the North Pacific victoria mode on the South China Sea Summer Monsoon. Atmosphere 9:229

Ding RQ, Tseng YH, Li J, Sun C, Xie F, Hou Z (2019) Relative contributions of North and South Pacific sea surface temperature anomalies to ENSO. J Geophys Res 124:6222-6237

Duan W, Song L, Yun L, Mao J (2013) Modulation of PDO on the predictability of the interannual variability of early summer rainfall over south China. J Geophys Res Atmos 118:13008-13021. https://doi.org/10.1002/2013JD019862

Easterling DR, Meehl GA, Parmesan C, Changnon SA, Karl TR, Mearns LO (2000) Climate extremes: observations, modeling, and impacts. Science 289:2068-2074

Feng X, Huang B, Kirtman BP, Kinter JL, Chiu LS (2017) A multimodel analysis of the resolution influence on precipitation climatology in the Gulf Stream region. Clim Dyn 48:1685-1704. https://doi.org/10.1007/s00382-016-3167-7

Gao T, Zhang Q, Luo M (2020) Intensifying effects of El Niño events on winter precipitation extremes in southeastern China. Clim Dyn 54:631-648. https://doi.org/10.1007/s00382-019-05022-6 
Hansen J, Hodges A, Jones J (1998) ENSO influences on agriculture in the Southeastern US. J Clim 11:404-411

Hersbach $\mathrm{H}$ et al (2018) Operational global reanalysis: progress, future directions and synergies with NWP. ERA Rep Ser 27:63

Huang W, Yang X, Li M, Zhang X, Wang M, Dai S, Ma J (2010) Evolution characteristics of seasonal drought in the south of China during the past 58 years based on standardized precipitation index (in Chinese). Trans Chin Soc Agric Eng 26:50-59. https://doi.org/ 10.3969/j.issn.1002-6819.2010.07.009

Huffman GJ et al (2007) The TRMM multisatellite precipitation analysis (TMPA): Quasi-global, multiyear, combined-sensor precipitation estimates at fine scales. J Hydrometeorol 8:38-55. https://doi. org/10.1007/978-90-481-2915-7_1

Kovats RS, Bouma MJ, Hajat S, Worral E, Haines A (2003) El Niño and health. Lancet 362:1481-1489

Li C, Ma H (2012) Relationship between ENSO and winter rainfall over Southeast China and its decadal variability. Adv Atmos Sci 29:1129-1141. https://doi.org/10.1007/s00376-012-1248-z

Li X, Yu J, Li Y (2013) Recent summer rainfall increase and surface cooling over Northern Australia: a response to warming in the tropical Western Pacific. J Clim 26:7221-7239

Li J, Zheng F, Sun C, Feng J, Wang J (2019) Pathways of influence of the northern hemisphere mid-high latitudes on East Asian climate: A review. Adv Atmos Sci 36:902-921. https://doi.org/ 10.1007/s00376-019-8236-5

Linkin ME, Nigam S (2008) The North Pacific Oscillation-west Pacific teleconnection pattern: mature-phase structure and winter impacts. J Clim 21:1979-1997. https://doi.org/10.1175/ 2007JCLI2048.1

Lu B, Scaife AA, Dunstone N, Smith D, Ren HL, Liu Y, Eade R (2017) Skillful seasonal predictions of winter precipitation over southern China. Environ Res Lett 12:074021. https://doi.org/10. 1088/1748-9326/aa739a

McCreary JP, Anderson DLT (1991) An overview of coupled oceanatmosphere models of El Niño and the Southern Oscillation. J Geophys Res 96:3125-3150

McGregor GR, Ebi K (2018) El Niño Southern Oscillation (ENSO) and health: an overview for climate and health researchers. Atmos 9:282. https://doi.org/10.3390/atmos9070282

Minobe S, Kuwano-Yoshida A, Komori N, Xie S-P, Small RJ (2008) Influence of the Gulf Stream on the troposphere. Nature 452:206-209. https://doi.org/10.1038/nature06690

Minobe S, Miyashita M, Kuwano-Yoshida A, Tokinaga H, Xie SP (2010) Atmospheric response to the Gulf Stream: seasonal variations. J Clim 23:3699-3719. https://doi.org/10.1175/2010J CLI3359.1

O’Neill LW, Haack T, Chelton DB, Skyllingstad E (2017) The Gulf Stream convergence zone in the time-mean winds. J Atmos Sci 74:2383-2412. https://doi.org/10.1175/JAS-D-16-0213.1

Philander SG (1990) El Niño, La Niña, and the Southern Oscillation. Int Geophys 46:1-289

Pu X, Chen QL, Zhong QJ, Ding RQ, Liu T (2019) Influence of the North Pacific Victoria mode on western North Pacific tropical cyclone genesis. Clim Dyn 52:245-256

Pyper B, Peterman R (1998) Comparison of methods to account for autocorrelation in correlation analyses of fish data. Can J Fish Aquat Sci 55:2127-2140

Qin D, Ding Y, Mu M (2015) Climate and environmental change in China: 1951-2012. Springer, Beijing

Ren HL, Jin FF (2011) Niño indices for two types of ENSO. Geophys Res Lett 38:L04704

Rogers JC (1981) The North Pacific Oscillation. J Climatol 1:39-57

Sasaki YN, Minobe S, Asai T, Inatsu M (2012) Influence of the Kuroshio in the East China Sea on the early summer (baiu) rain. J Clim 25:6627-6645
Sui Y, Jiang D, Tian Z (2013) Latest update of the climatology and changes in the seasonal distribution of precipitation over China. Theor Appl Climatol 113:599-610. https://doi.org/10.1007/ s00704-012-0810-z

Sun X, Renard B, Thyer M, Westra S, Lang M (2015) A global analysis of the asymmetric effect of ENSO on extreme precipitation. J Hydrol 530:51-65

Sun Y, Liu JW, Xie SP (2020) North Atlantic Oscillation effect on interannual variability in winter precipitation over the gulf stream. J Clim 33:6633-6649. https://doi.org/10.1175/ JCLI-D-19-0515.1

Trenberth KE, Stepaniak DP, Caron JM (2000) The global monsoon as seen through the divergent atmospheric circulation. J Clim 13:3969-3993

Trenberth KE, Fasullo JT, Mackaro J (2011) Atmospheric moisture transports from ocean to land and global energy flows in reanalyses. J Clim 24:4907-4924. https://doi.org/10.1175/2011JCLI41 71.1

Vimont DJ, Battisti DS, Hirst AC (2001) Footprinting: a seasonal connection between the tropics and mid-latitudes. Geophys Res Lett 28:3923-3926

Vimont DJ, Battisti DS, Hirst AC (2003a) The seasonal footprinting mechanism in the CSIRO general circulation models. J Clim 16:2653-2667

Vimont DJ, Wallace JM, Battisti DS (2003b) The seasonal footprinting mechanism in the Pacific: implications for ENSO. J Clim $16: 2668-2675$

Walker GT (1923) Correlation in seasonal variations of weather: A preliminary study of world weather. Mem India Meteorol Dep 24:75-131

Walker GT (1925) Correlation in seasonal variations of weather: A further study of world weather. Mon Weather Rev 53:252-254

Wang B, Wu R, Fu X (2000) Pacific-East Asian teleconnection: How does ENSO affect East Asian climate? J Clim 13:1517-1536. https://doi.org/10.1175/1520-0442(2000)013,1517:PEATHD. 2.0.CO;2

Wang Q, Cai W, Zhong W, Zeng L, Wu L, Wang D (2019) Response of Southern China winter rainfall to El Niño diversity and its relevance to projected Southern China Rainfall change. J Clim 32:3343-3356

Wu R, Hu Z, Kirtman BP (2003) Evolution of ENSO-related rainfall anomalies in East Asia. J Clim 16:3742-3758. https://doi.org/10. 1175/1520-0442(2003)016,3742:EOERAI.2.0.CO;2

Wu ZW, Wang B, Li JP, Jin FF (2009) An empirical seasonal prediction model of the East Asian summer monsoon using ENSO and NAO. J Geophys Res 114:D18120. https://doi.org/10.1029/2009J D011733

Wu B, Li T, Zhou T (2010) Asymmetry of atmospheric circulation anomalies over the western North Pacific between El Niño and La Niña. J Clim 23:4807-4822. https://doi.org/10.1175/2010J CLI3222.1

Wu ZW, Li JP, Jiang ZH, Ma TT (2012) Modulation of the Tibetan Plateau snow cover on the ENSO teleconnections: from the East Asian summer monsoon perspective. J Clim 25:2481-2489. https://doi.org/10.1175/JCLI-D-11-00135.1

Wu B, Zhou T, Li T (2017) Atmospheric dynamic and thermodynamic processes driving the western North Pacific anomalous anticyclone during El Niño. Part I: maintenance mechanisms. J Clim 30:9621-9635. https://doi.org/10.1175/JCLI-D-16-0489.1

Xie SP, Hafner J, Tanimoto Y, Liu WT, Tokinaga H, Xu H (2002) Bathymetric effects on the winter sea surface temperature and climate of the Yellow and East China Seas. Geophys Res Lett 29:2228

Xu H, Xu M, Xie SP, Wang Y (2011) Deep atmospheric response to the spring Kuroshio over the East China Sea. J Clim 24:4959-4972 
Xu G, Chang P, Ma X, Li M (2019) Suppression of winter heavy precipitation in Southeastern China by the Kuroshio warm current. Clim Dyn 53:2437-2450. https://doi.org/10.1007/ s00382-019-04873-3

Yuan Y, Li C, Yang S (2014) Decadal anomalies of winter precipitation over southern China in association with El Niño and La Niña. Acta Meteorol Sin 28:91-110. https://doi.org/10.1007/ s13351-014-0106-6

Zhang R, Sumi A (2002) Moisture circulation over East Asia during El Niño episode in northern winter, spring and autumn. J Meteorol Soc Jpn 80:213-227. https://doi.org/10.2151/jmsj.80.213

Zhang L, Fraedrich K, Zhu X, Sielmann F, Zhi X (2015) Interannual variability of winter precipitation in Southeast China. Theor Appl Climatol 119:229-238. https://doi.org/10.1007/ s00704-014-1111-5

Zhang R, Min Q, Su J (2017) Impact of El Niño on atmospheric circulations over East Asia and rainfall in China: role of the anomalous western North Pacific anticyclone. Sci China Earth Sci 60:11241132. https://doi.org/10.1007/s11430-016-9026-X

Zhang P, Wang B, Wu Z (2019a) Weak El Niño and Winter Climate in the mid-to high-latitude Eurasia. J Clim 32:402-421
Zhang P, Wu Z, Li J (2019b) Reexamining the relationship of La Niña and the East Asian winter monsoon. Clim Dyn 53:779-791

Zhang P, Wu Z (2021) Reexamining the connection of El Niño and North American winter climate. Int J Climatol 41:6133-6144

Zhou LT, Wu R (2010) Respective impacts of the East Asian winter monsoon and ENSO on winter rainfall in China. J Geophys Res Atmos 115:D02107. https://doi.org/10.1029/2009JD012502

Zhou LT, Tam C, Zhou W, Chan JC (2010) Influence of South China Sea SST and the ENSO on winter rainfall over South China. Adv Atmos Sci 27:832-844

Zou Q, Ding RQ, Li JP, Tseng YH, Hou ZL, Wen T, Ji K (2020) Is the North Pacific victoria mode a predictor of winter rainfall over South China? J Clim 33:8833-8847

Publisher's Note Springer Nature remains neutral with regard to jurisdictional claims in published maps and institutional affiliations. 